\title{
\$1 Billion drug deal creates debt for "tomorrow's AIDS orphans"
}

Annabel Ferriman, $B M J$

The United States has offered sub-Saharan African nations a $\$ 1$ billion loan program to buy anti-AIDS drugs. The new program was announced in Washington, DC, last week by the congressionally funded US ExportImport Bank. It involves 5-year loans to 24 eligible countries at interest rates of about $7 \%$ a year.

The offer has been condemned by Oxfam as "a debt that tomorrow's AIDS orphans will be forced to pay."

The US offer requires countries to buy drugs manufactured in the United States. Oxfam said that the loan would simply load more debt on countries that were already among the poorest in the world. "The deal amounts to a credit-line which locks poor countries into buying expensive patented drugs, when what they need is help to make or buy low-cost generic equivalents," Oxfam said in a press release.
It continued: "The G8 nations promised last year to write off $\$ 100$ billion worth of poor country debt. But little of that has been delivered. For the US this week to offer these same poor countries another $\$ 1$ billion of debt is wrong-headed." The debt owed by sub-Saharan African nations currently stands at $\$ 15.2$ billion.

"This offer has been publicized as an act of kindness toward Africa's 24.5 million sufferers of HIV and AIDS. In fact, the money will flow straight into the pockets of the US pharmaceutical industry," said an Oxfam spokesperson.

Oxfam accused the United States of setting up the deal to help the drug companies fight off competition from generic drugs that can be manufactured locally. Brazil and India, for example, currently manufacture antiAIDS drugs at a fraction of the cost of those marketed by multinational pharmaceutical companies.
The companies consider these generic drugs to be a violation of intellectual property that the companies say is protected by patents and trade agreements enforced by the World Trade Organization.

The anti-AIDS drug stavudine, for example, costs $\$ 6.10$ per daily dose in Uganda, where it is marketed by Bristol-Myers Squibb, but just 55 cents in Brazil, where it is produced generically. Brazil and India are among the few countries in the world that started local production of anti-AIDS drugs before the World Trade Organization's rules on intellectual property rights were applied.

"The best way to begin helping the poor countries of sub-Saharan Africa is to cancel their debt so they can invest in health, education, and development," an Oxfam spokesman said.

Islet cell transplantation may be feasible President Clinton has named 6 centers that will participate in a trial in which 40 people with type 1 diabetes mellitus will receive islet cell transplants. In a recent case series, 7 diabetic patients had normal glycosylated hemoglobin levels for a median of 11.9 months after islet cell transplantation. The progress of the technique is likely to be impeded by the shortage of donor pancreases, the primary source of islets. 